\title{
Do the seasonal forests in northeastern Brazil represent a single floristic unit?
}

\author{
Rodal, MJN. ${ }^{\mathrm{a} *}$, Barbosa, MRV. ${ }^{\mathrm{b}}$ and Thomas, $W W^{\mathrm{c}}$ \\ aDepartamento de Biologia, Universidade Federal Rural de Pernambuco - UFRPE, \\ Rua Dom Manoel de Medeiros, s/n, CEP 52171-900, Recife, PE, Brazil \\ ${ }^{\text {b} D e p a r t a m e n t o ~ d e ~ S i s t e m a ́ t i c a ~ e ~ E c o l o g i a, ~ U n i v e r s i d a d e ~ F e d e r a l ~ d a ~ P a r a i ́ b a ~-~ U F P B, ~}$ \\ CP 5065, CEP 58051-970, João Pessoa, PB, Brazil \\ 'Institute of Systematic Botany, The New York Botanical Garden, \\ Bronx, NY, 10458-5126, USA \\ *e-mail: mrodal@terra.com.br
}

Received August 17, 2006 - Accepted July 27, 2007 - Distributed August 31, 2008

(With 2 figures)

\begin{abstract}
Floristic analyses (Principal Component Analysis and Analysis of Group Indicators) at the genus level were employed to characterize and compare seasonal forest formations in northeastern Brazil. The presence - absence of 248 genera of woody plants occurring in 24 floristic surveys was correlated with geomorphology and climatic variables. The analyses were consistent and point to the existence of two floristic groups of seasonal forests in the region, one more closely related to the Atlantic Coastal Forest (mata atlântica) and the other to the xerophytic formations (caatinga) of the region. The driest seasonal forest group experiences more than 8 dry months per year and/or a total annual rainfall of $<1000 \mathrm{~mm}$, and is found on the ancient eroded peaks in the semi-arid core and on the western slopes of the Borborema Plateau.
\end{abstract}

Keywords: diversity, tropical dry forest, caatinga, Atlantic coastal forest.

\section{As florestas estacionais do nordeste brasileiro representam uma única unidade florística?}

\section{Resumo}

Análises florísticas no nível genérico (análise de componentes principais e análise de grupos indicadores) foram realizadas com o objetivo de caracterizar e comparar as formações florestais estacionais do Nordeste oriental brasileiro. A presença - ausência de 248 gêneros de plantas lenhosas presentes em 24 levantamentos florísticos foi correlacionada com a geomorfologia e variáveis climáticas. As análises foram consistentes e apontaram a existência de dois grupos florísticos de florestas estacionais, um mais relacionado às florestas litorâneas (mata atlântica) e outro às formações xerofíticas (caatinga). O grupo das florestas estacionais mais secas sofre pelo menos oito meses de seca por ano e recebe no máximo 1000 mm per year de precipitação, sendo estas encontradas sobre os picos elevados da região semiárida e na encosta ocidental do planalto da Borborema.

Palavras-chave: diversidade, floresta tropical seca, caatinga, Floresta Atlântica costeira.

\section{Introduction}

In northeastern Brazil, seasonal forests are most common at the transition between the Atlantic Coastal Forest and the caatinga, the deciduous, thorny, xerophytic inland vegetation predominant in this region. Seasonal forests also occur, however, within the Depressão Sertaneja, the core area of caatinga, on scattered ancient peaks where the higher elevation increases humidity.

Northeastern Brazilian seasonal forests experience a marked alternation between rainy and dry seasons, and exhibit a seasonal loss of new leaves in response to variations in water stress (Veloso et al., 1991). In a broad sense, northeastern seasonal forests can be classified as dry forests, (Gentry, 1995; Pennington et al., 2000), but are given many local designations, corresponding to their perceived degree of humidity (e.g., mesophytic forest, dry forest, liana forest and agreste). Andrade-Lima (1966), indeed, distinguished moist and dry seasonal forests in northeastern Brazil based on their physiognomy and the climatic characteristics of their sites.

Gentry (1995) observed that neotropical dry forests occur in areas where the precipitation varies between 700 and $1600 \mathrm{~mm}$ per year, with a period of at least 
5-6 months in which less than $100 \mathrm{~mm}$ of precipitation is received each month. Pennington et al. (2000) reaffirmed the upper limit of $1600 \mathrm{~mm}$ per year of precipitation and, while they did not explicitly state a minimum limit of precipitation, the descriptions of the diverse physiognomies a seasonal dry forest might have, and the fact that they follow Murphy and Lugo's (1986, 1995) limits, suggest a lower limit of $200 \mathrm{~mm}$ per year. Their concept of dry forests is much broader than Gentry's and includes plant formations as diverse as tall forest on moister sites and cactus scrub on the driest. In this sense, they considered the semi-arid caatinga as one of the largest areas of seasonal dry tropical forest. Pennington et al. (2000, 2004), noting the existence of strong floristic links between well separated areas of seasonally dry forest in South America, suggested that these areas are in fact fragments of an older and much larger forest formation, a neotropical seasonally dry forest biome which includes the caatinga. They cited data from molecular biogeographical studies suggesting that, in many cases, the speciation of trees and shrubs in the dry forest of South America pre-dates the Pleistocene.

Behling et al. (2000), however, found that pollen data from northeastern Brazil reflected primarily open caatinga vegetation and the occurrence of caatinga vegetation in northeastern Brazil during the recorded part of the last glacial and early Holocene periods $(42,000-$ 8500 14C yr BP).

Also, in contrast to Pennington et al. (2000), Oliveira-Filho et al. (2006) argued that it only makes sense to include caatinga as neotropical dry forest if the cerrado, which also incorporates fragments of seasonal forests (Nascimento et al., 2004), is also included within the concept of seasonal dry tropical forest.

While we recognize that there is a range of opinions as to the limits of seasonal forests, we are following the vegetation classification of Veloso et al. (1991) and the concepts of Gentry (1995) which recognize caatinga as distinct from seasonal forest.

In this study, northeastern Brazilian seasonal forests, both along the Atlantic Coastal Forest - caatinga contact zone as well as on scattered peaks within the caatinga, were examined to determine if they comprised one or more floristic groups. This was done by comparing the distribution of woody genera at different sites located between the regional climatic extremes, the semi-arid caatinga vegetation and the moist Atlantic Coastal Forest.

Additionally, possible relations between the spatial distribution of abiotic factors (principally climatic) and the forest communities were investigated. We also tested if the limits for seasonally dry tropical forests proposed by Gentry (1995) and Pennington et al. (2000) could be applied to Brazilian northeastern seasonal forests.

\section{Methods}

\subsection{Study area}

The eastern portion of Brazil's Northeast comprises the states of Rio Grande do Norte, Paraíba, Pernambuco,
Alagoas and Sergipe. The Borborema Plateau, a series of highly weathered massifs, is the principal geomorphological feature and crosses the region in a N-S direction forming the eastern limit of the semi-arid region. It is composed principally of metamorphosed rocks, such as gneisses and eruptive granites (Andrade, 1977; Moreira, 1977), and shows high geomorphological and vegetational diversity.

Descending east from these highlands towards the coast, the Pre-Cambrian rocks of the Borborema Plateau are replaced by the hills and coastal plains of the Barreiras Formation (Tertiary). The predominant vegetation there ranges from moist to seasonal forests, with both types locally called Atlantic Coastal Forest. To the west, the Borborema Plateau slopes steeply down towards the semi-arid core region, the Depressão Sertaneja, with its dry caatinga vegetation. Scattered within this basin are a number of ancient eroded peaks (Jatobá, 1983) which often have seasonal forest vegetation quite distinct from the spiny, deciduous caatinga.

Floristic and ecological analysis - Twenty-four floristic lists selected from local or regional literature or from unpublished data by the authors (Table 1) in the states of Paraíba, Pernambuco and Sergipe, where intensive collections were undertaken, were analyzed. These lists represent the variety of different and distinct physiognomies found within the regional climatic extremes - from scrub caatinga to moist forest. Table 2 presents the vegetation physiognomy and abiotic variables of each selected area. The classification of each forest area as moist or seasonal is based on the criteria of Veloso et al. (1991). Total annual rainfall and the number of dry months per year $(<100 \mathrm{~mm}$ of rainfall per month) were obtained from data presented in the individual studies or from federal meteorological data (SUDENE, 1990a; b; c); geomorphological information as well as elevation are from Silva et al. (1993).

Considering the methodological differences in developing the floristic lists used in this analysis (Table 1), we chose to consider only trees, shrubs and arborescent cacti, since other habits were not consistently collected. In order to minimize the potential differences in usage of species names in different lists, each list was checked for consistency of synonyms and up-to-date usage. In addition, floristic comparisons were made only at the generic level to eliminate misidentifications at the species level.

Using these data, a binary matrix was constructed, plotting the presence - absence of 248 genera in each area. Analyses were undertaken to determine: 1) groups of areas with similar floristic sets and 2) taxonomic group indicators for those areas, using Principal Components Analysis - PCA (Gauch, 1982) and Analysis of Indicators - TWINSPAN (Hill, 1979), respectively.

TWINSPAN is a technique developed for hierarchical classification of community data, and was used in order to identify possible hierarchical relationships between associations of genera among the different lists. The technique is based on the concept that any groups of 
Table 1. Location of floristic surveys named according to municipality or geographic region (*) in Northeastern Brazil, with references.

\begin{tabular}{|c|c|c|c|}
\hline Areas & (With geocoordinates) & & References \\
\hline 01 & Cabo & $\left(8^{\circ} 15^{\prime} \mathrm{S}\right.$ and $\left.35^{\circ} 02^{\prime} \mathrm{W}\right)$ & Siqueira et al. (2001) \\
\hline 02 & João Pessoa & $\left(7^{\circ} 07^{\prime} \mathrm{S}\right.$ and $\left.34^{\circ} 53^{\prime} \mathrm{W}\right)$ & Barbosa (1996) \\
\hline 03 & Mamanguape & $\left(6^{\circ} 50^{\prime} \mathrm{S}\right.$ and $\left.35^{\circ} 07^{\prime} \mathrm{W}\right)$ & Barbosa (unpublished data) \\
\hline 04 & Recife & $\left(8^{\circ} 03^{\prime} \mathrm{S}\right.$ and $\left.34^{\circ} 56^{\prime} \mathrm{W}\right)$ & Guedes (1998) \\
\hline 05 & Caruaru II & $\left(8^{\circ} 17^{\prime} \mathrm{S}\right.$ and $\left.35^{\circ} 58^{\prime} \mathrm{W}\right)$ & Tavares et al. (2000) \\
\hline 06 & Areia II & $\left(6^{\circ} 58^{\prime} \mathrm{S}\right.$ and $\left.35^{\circ} 42^{\prime} \mathrm{W}\right)$ & Barbosa et al. (2004) \\
\hline 07 & Areia I & $\left(6^{\circ} 58^{\prime} \mathrm{S}\right.$ and $\left.35^{\circ} 42^{\prime} \mathrm{W}\right)$ & Pereira et al. (2002) \\
\hline 08 & Caruaru I & $\left(8^{\circ} 17^{\prime} \mathrm{S}\right.$ and $\left.35^{\circ} 58^{\prime} \mathrm{W}\right)$ & Alcoforado-Filho et al. (2003) \\
\hline 09 & Serra Talhada II & $\left(7^{\circ} 59^{\prime} \mathrm{S}\right.$ and $35^{\circ} 1^{\circ} 8^{\prime} \mathrm{W}$ ) & Ferraz et al. (1998) \\
\hline 10 & Sousa & $\left(6^{\circ} 45^{\prime} \mathrm{S}\right.$ and $\left.38^{\circ} 13^{\prime} \mathrm{W}\right)$ & Gadelha-Neto and Barbosa (2000) \\
\hline 11 & Vale do Piranhas $(*)$ & $\left(6^{\circ} 28^{\prime} \mathrm{S}\right.$ and $\left.38^{\circ} 09^{\prime} \mathrm{W}\right)$ & Tavares et al. (1975) \\
\hline 12 & Serra Talhada I & $\left(8^{\circ} 15^{\prime} \mathrm{S}\right.$ and $\left.35^{\circ} 02^{\prime} \mathrm{W}\right)$ & Ferraz et al. (1998) \\
\hline 13 & Petrolina & $\left(9^{\circ} 23^{\prime} \mathrm{S}\right.$ and $\left.40^{\circ} 30^{\prime} \mathrm{W}\right)$ & Drummond et al. (1979) \\
\hline 14 & Custódia & $\left(8^{\circ} 18^{\prime} \mathrm{S}\right.$ and $\left.38^{\circ} 35^{\prime} \mathrm{W}\right)$ & Rodal (1992) \\
\hline 15 & Pesqueira & $\left(8^{\circ} 22^{\prime} \mathrm{S}\right.$ and $\left.36^{\circ} 42^{\prime} \mathrm{W}\right)$ & Correia (1996) \\
\hline 16 & Campina Grande & $\left(7^{\circ} 13^{\prime} \mathrm{S}\right.$ and $\left.35^{\circ} 52^{\prime} \mathrm{W}\right)$ & Lourenço and Barbosa (2003) \\
\hline 17 & São Lourenço da Mata & $\left(8^{\circ} 02^{\prime} \mathrm{S}\right.$ and $\left.35^{\circ} 07^{\prime} \mathrm{W}\right)$ & Andrade and Rodal (2004) \\
\hline 18 & Floresta II & $\left(8^{\circ} 35^{\prime} \mathrm{S}\right.$ and $\left.38^{\circ} 02^{\prime} \mathrm{W}\right)$ & Rodal and Nascimento (2002) \\
\hline 19 & Floresta I & $\left(8^{\circ} 35^{\prime} \mathrm{S}\right.$ and $\left.38^{\circ} 02^{\prime} \mathrm{W}\right)$ & Rodal and Nascimento (2002) \\
\hline 20 & Triunfo II & $\left(7^{\circ} 50^{\prime} \mathrm{S}\right.$ and $\left.38^{\circ} 07^{\prime} \mathrm{W}\right)$ & Ferraz et al. (1998) \\
\hline 21 & Triunfo I & $\left(7^{\circ} 50^{\prime} \mathrm{S}\right.$ and $\left.38^{\circ} 07^{\prime} \mathrm{W}\right)$ & Ferraz et al. (1998) \\
\hline 22 & São José da Lagoa Tapada & $\left(6^{\circ} 59^{\prime} \mathrm{S}\right.$ and $\left.17^{\circ} 59^{\prime} \mathrm{W}\right)$ & Barbosa (unpublished data) \\
\hline 23 & Nossa Senhora da Glória & $\left(10^{\circ} 33^{\prime} \mathrm{S}\right.$ and $\left.37^{\circ} 32^{\prime} \mathrm{W}\right)$ & Souza (1983) \\
\hline 24 & Frei Paulo & $\left(10^{\circ} 13^{\prime} \mathrm{S}\right.$ and $\left.37^{\circ} 25^{\prime} \mathrm{W}\right)$ & Souza (1983) \\
\hline
\end{tabular}

samples which constitute the same community type will have a corresponding group of same indicator species (Kent and Coker, 1992).

We interpreted the results correlating them with abiotic factors in order to identify possible explanations to the floristic patterns found.

\section{Results}

Along the first axis of the PCA analysis (Figure 1) we observed the formation of two sets of surveys: 1) those which incorporated Cabo, Recife (moist forests), Areia II, São Lourenço da Mata, Caruaru II, Mamanguape, João Pessoa and Pesqueira (seasonal forests); and 2) those which included all the other areas. Along the second axis (Figure 1) there is a gradient which has, as one of its extremes, the studies carried out within the caatinga domain (Serra Talhada I and II, Vale do Piranhas, Custódia, Petrolina, Sousa, Nossa Senhora da Glória, Frei Paulo, and Caruaru I) and, as the other extreme, the seasonal forests that occupy the eroded peaks of the Depressão Sertaneja as well as the western slopes of the Borborema Plateau (Floresta I and II, Triunfo I and II, and São José da Lagoa Tapada).

As shown in Table 2, the surveys in the first set experience less than 8 dry months per year and/or a total annual rainfall $>1000 \mathrm{~mm}$. They are found in the lowlands along the coastal plain, on the eastern slope of the Borborema Plateau, and in the transition zone in between them. Those second set of surveys comprise those that experience more than 8 dry months per year and/or a total annual rainfall $<1000 \mathrm{~mm}$. They are found in the semi-arid core, both in the Depressão Sertaneja as well as on the ancient eroded peaks in the area, and on the western slopes of the Borborema Plateau.

Figure 2 shows the dendrogram derived from the TWINSPAN analysis. The genera identified as indicators for the first set of surveys (the same areas separated by PCA) were: Tapirira and Thyrsodium (Anacardiaceae), Guatteria (Annonaceae), Himathanthus (Apocynaceae), Protium (Burseraceae), Licania (Chrysobalanaceae), Vismia (Clusiaceae), Chaetocarpus and Pogonophora (Euphorbiaceae), Eschweilera (Lecythidadaceae), Byrsonima (Malpighiaceae),Miconia(Melastomataceae), Brosimum (Moraceae), Cupania (Sapindaceae) and Psychotria (Rubiaceae), among others (Table 3).

The indicator genera for the second set of surveys were: Myracrodruon and Schinopsis (Anacardiaceae), Aspidosperma (Apocynaceae), Tabebuia (Bignoniaceae), Cereus (Cactaceae), Croton (Euphorbiaceae), Piptadenia, 
Rodal, MJN., Barbosa, MRV. and Thomas, WW.

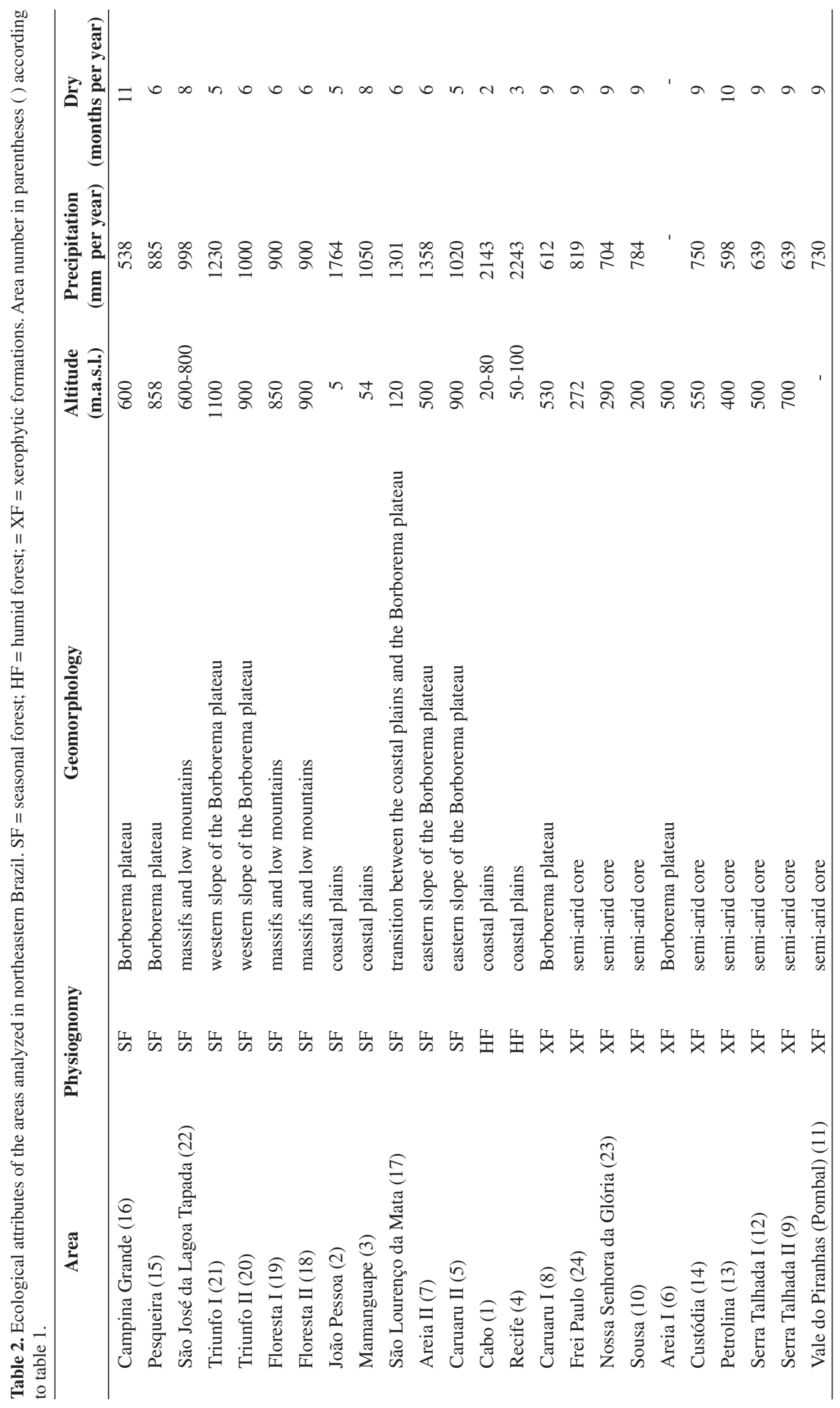




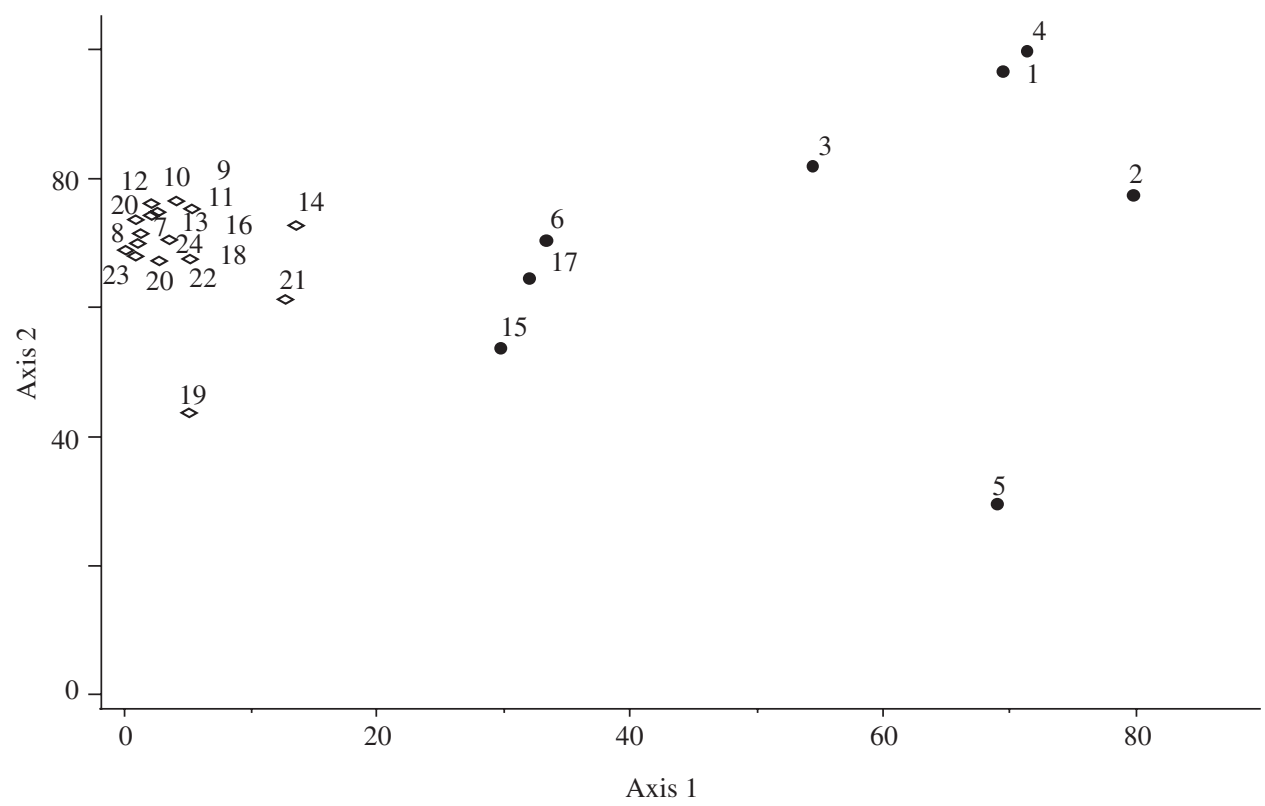

Figure 1. Principal Component Analysis diagram showing the relationship of the 24 surveys examined. HF = humid forests, $\mathrm{SF}=$ seasonal forest, $\mathrm{XF}=$ xerophytic formations. Area number $(1 \ldots 24)$ corresponds to the numbers in table 1 .

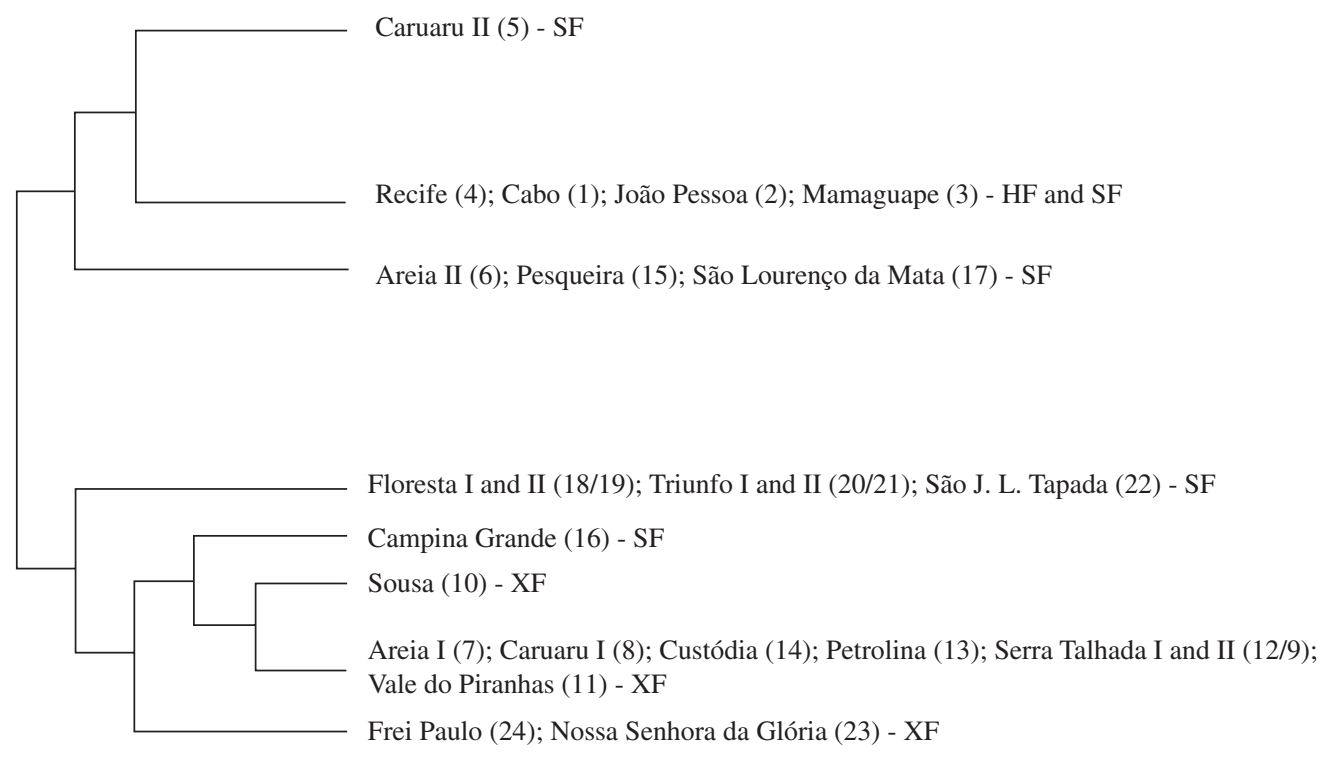

Figure 2. TWINSPAN dendrogram showing the relationship of the 24 surveys examined. $\mathrm{HF}=$ humid forests, $\mathrm{SF}=$ seasonal forest, $\mathrm{XF}=$ xerophytic formations.

Mimosa and Senna (Leguminosae) and Ziziphus (Rhamnaceae), among others (Table 3).

The TWINSPAN identified two subgroups within the second group: one found in areas of the Depressão Sertaneja and characterized as Commiphora (Burseraceae), Pilosocereus (Cactaceae), Capparis
(Capparaceae), Acalypha (Euphorbiaceae), Caesalpinia and Anadenanthera (Leguminosae), among others (Table 3). The second sub-group is found on the ancient eroded peaks and western slopes of the Borborema Plateau is characterized as Rollinia (Annonaceae), Syagrus (Arecaceae), Zeyhera (Bignoniaceae), Diospyros 
Table 3. Indicator genera for groupings (sets) of areas of the 24 surveys analyzed.

\section{Indicator genera for the first set (Humid Group) of surveys}

Tapirira, Thyrsodium (Anacardiaceae), Anaxagorea, Annona, Guatteria, Xylopia (Annonaceae),

Himatanthus, Tabernaemontana (Apocynaceae), Ilex (Aquifoliaceae), Schefflera (Araliaceae),

Eriotheca (Bombacaeae), Protium (Burseraceae), Cecropia (Cecropiaceae), Maytenus (Celastraceae),

Hirtella, Licania (Chrysobalanaceae), Clusia, Symphonia, Vismia (Clusiaceae), Buchenavia (Combretaceae),

Rourea (Connaraceae), Sloanea (Elaeocarpaceae), Chaetocarpus, Pera, Pogonophora (Euphorbiaceae),

Casearia (Flacourtiaceae), Sacoglottis (Humiriaceae), Lacistema (Lacistemaceae), Ocotea (Lauraceae),

Eschweilera, Lecythis (Lecythidaceae), Apuleia, Chamaecrista, Dialium, Hymenaea, Peltophorum,

Sclerolobium (Leguminosae Caesalpinioideae), Andira, Bowdichia, Machaerium, Ormosia, Pterocarpus,

Swartzia, (Leguminosae Faboideae), Abarema, Albizia, Inga, Macrosamanea, Parkia, Stryphnodendron

(Leguminosae Mimosoideae), Byrsonima, Tetrapteris (Malpighiaceae), Miconia (Melastomataceae),

Guarea, Trichilia (Meliaceae), Brosimum, Ficus, Sorocea (Moraceae), Myrsine (Myrsinaceae),

Campomanesia, Myrcia, Psidium (Myrtaceae), Guapira (Nyctaginaceae), Ouratea (Ochnaceae),

Schoepfia (Olacaceae), Piper (Piperacaeae), Coccoloba (Polygonaceae), Roupala (Proteaceae),

Colubrina (Rhamnaceae), Alibertia, Amaioua, Chomelia, Coussarea, Posoqueria, Psychotria (Rubiaceae),

Cupania (Sapindaceae), Chrysophyllum, Manilkara, Micropholis, Pouteria, Pradosia (Sapotaceae),

Picramnia, Simarouba (Simaroubaceae), Brunfelsia (Solanaceae), Guazuma (Sterculiaceae), Apeiba,

Luehea (Tiliaceae), Vitex (Verbenaceae), Rinorea (Violaceae).

Indicator genera for the second set of (Dry Group) of surveys

Myracrodruon, Schinopsis, Spondias (Anacardiaceae) Rollinia (Annonaceae), Ceiba, Pseudobombax

(Bombacaceae), Commiphora (Burseraceae), Cereus, Opuntia, Pilosocereus (Cactaceae), Capparis

(Capparaceae), Combretum (Combretaceae) Diospyros (Ebenaceae), Croton, Jatropha, Manihot, Maprounea,

Sapiu, (Euphorbiaceae), Bauhinia, Caesalpinia (Leguminosae Caesalpinioideae), Amburana (Leguminosae

Faboideae), Acacia, Anadenanthera, Mimosa, Parapiptadenia, Piptadenia (Leguminosae Mimosoideae),

Cedrela (Meliaceae) Ruprechtia (Polygonaceae), Ziziphus (Rhamnaceae), Guettarda, Randia (Rubiaceae), Zanthoxylum (Rutaceae), Sideroxylon (Sapotaceae) Helicteres (Sterculiaceae).

Indicator genera for one subset of the second survey (Dry Group)

Depressão sertaneja - Commiphora (Burseraceae), Pilosocereus (Cactaceae), Capparis (Capparaceae),

Acalypha (Euphorbiaceae) Caesalpinia (Leguminosae Caesalpinioideae), Derris, Erythrina (Leguminosae

Faboideae), Anadenanthera, Chloroleucon, Mimosa, Pithecellobium (Leguminosae Mimosoideae),

Ximenia (Olacaeae), Sideroxylon (Sapotaceae).

\begin{tabular}{l} 
Indicator genera for a second subset of the second survey (Dry Group) \\
\hline Ancient eroded peaks and western slopes of the Borborema Plateau - Rollinia (Annonaceae), Syagrus \\
(Arecaceae) Jacaranda, Zeyheria (Bignoniaceae), Pseudobombax (Bombacaceae), Garcinia (Clusiaceae), \\
Buchenavia, Terminalia (Combretaceae), Diospyros (Ebenaceae), Erythroxylum (Erythroxylaceae), \\
Sebastiana (Euphorbiaceae), Casearia, Prockia, Xylosma (Flacourtiaceae), Ocotea (Lauraceae), Copaifera, \\
Hymenaea, Pterogyne (Leguminosae Caesalpinioideae), Amburana, Crotalaria, Indigofera, Machaerium, \\
Platymiscium (Leguminosae Faboideae), Albizia, Enterolobium, Inga (Leguminosae Mimosoideae), \\
Banisteriopsis, Bunchosia, Byrsonima, Tetrapterys, Tryallis (Malpighiaceae), Herissantia (Malvaceae), \\
Miconia (Melastomataceae), Trichilia (Meliaceae), Brosimum, Ficus (Moraceae), Myrsine (Myrsinaceae), \\
Calyptranthes, Campomanesia, Marlierea Myrcia, Myrciaria, Psidium (Myrtaceae), Ouratea (Ochnaceae), \\
Schoepfia (Olacaceae) Coccoloba, Ruprechtia (Polygonaceae), Roupala (Proteaceae), Rhamnidium \\
(Rhamnaceae), Alibertia, Chomelia, Genipa, Randia, Rudgea, Tocoyena (Rubiaceae), Zanthoxylum (Rutaceae), \\
Cupania, Talisia (Sapindaceae), Chrysophyllum, Manilkara (Sapotaceae), Picrasma (Simaroubaceae), \\
Cestrum, Solandra, Solanum (Solanaceae), Guazuma (Sterculiaceae), Luehea (Tiliaceae), Celtis (Ulmaceae), \\
Urera (Urticaceae), Aloysia, Vitex (Verbenaceae), Qualea (Vochysiaceae).
\end{tabular}

(Ebenaceae), Sebastiania (Euphorbiaceae), Rupretchia (Polygonaceae) and Randia (Rubiaceae), among others (Table 3).

\section{Discussion}

Both the PCA (Figure 1) and TWINSPAN (Figure 2) analyses formed two groups comprising the same areas and consistent with the interpretation of the ecological data (Table 2).

The first set of surveys (Humid Group) includes moist and seasonal forests found in the lowlands along the coastal plains, on the eastern slopes of the Borborema Plateau, and in the transition zone between them, wherever the exposure to humid coastal winds makes possible 
the establishment of more humid forests. The indicator genera of this group are mostly rain forest taxa whose distributions extend to the adjacent seasonal forest (Barbosa, 1996; Barbosa et al., 2004; Rodal et al., 2005; Rodal and Nascimento, 2006).

The second set of surveys (Dry Group) occupies the semi-arid core and its scattered eroded peaks as well as the western slopes and the western sector of the Borborema Plateau. It includes both caatinga and seasonal forests. These seasonal forests, however, are drier than those in the Humid Group and suffer at least nine dry months per year. Genera such as Myracrodruon and Schinopsis (Anacardiaceae), Aspidosperma (Apocynaceae), Tabebuia (Bignoniaceae), Cereus (Cactaceae), Croton (Euphorbiaceae), Piptadenia, Mimosa and Senna (Leguminosae) and Ziziphus (Rhamnaceae), indicator genera of this set, are common in various arid plant formations (usually non-forest formations) of South America (Sarmiento, 1975). We note, however, that Rollinia (Annonaceae), Syagrus (Arecaceae), Zeyhera (Bignoniaceae), Diospyros (Ebenaceae), Sebastiania (Euphorbiaceae), Rupretchia (Polygonaceae) and Randia (Rubiaceae), occur only in forest formations and are not found in true caatinga.

These results indicate the presence of two floristic groups within the Northeastern seasonal forest: one with floristic links with the Atlantic Coastal Forest (Humid Group), and the other linked floristically to the semi-arid vegetation (Dry Group), including the caatinga. In the Humid Group, knowledge of the flora indicates that the seasonal forests are a subset of the moister forests and reflect a gradient of available moisture (Barbosa, 1996; Andrade and Rodal 2004; Rodal et al., 2005) with an elevated number of shared taxa. In the Dry Group, however, it is important to note that while seasonal forests have genera in common with the caatinga, the floristic connection between the two are not clear. Also, the flora of the caatinga cannot be considered merely a subset of the flora of the drier seasonal forests. While it is known that in the "semi-arid", physiognomy changes along a precipitation gradient (Sampaio et al., 1981; Ferraz et al., 2003), the substitution of species along the gradient is not gradual as it is in the Humid Group. In addition, Giulietti et al. (2002) list the occurrence of a significant number of species endemic to the caatinga. Further analysis of biogeographic questions, however, is limited by the lack of phylogenetic data available on plants of arid regions (Pennington et al., 2004).

Two areas merit attention in this analysis, Pesqueira and Triunfo. In the PCA analysis, Pesqueira was positioned intermediate between the seasonal forests of the Humid Group and those of the Dry Group, while in the TWINSPAN analysis it was placed with the Humid Group. It is important to note that Pesqueira is located on a peak in the central portion of the Borborema Plateau in the marginal zone of influence of the humid flora and, although it has ecological characteristics of the forests of the Dry Group, the floristic data show the relation of its flora with that of the Humid Group. The Triunfo site on the other hand, due to its higher altitude (900-1100 m) and its exposure to humid winds, retains ecological characteristics of the Humid Group (>1000 mm rainfall per year and 5 dry months). Its generic flora is, however, similar to that of the seasonal forests of the Dry Group.

Although Gentry (1995) recognized that Neotropical dry forests occur in areas with precipitation between 700 and $1600 \mathrm{~mm}$ and at least 5 to 6 dry months per year, at a regional scale, Andrade-Lima (1981) considered $1000 \mathrm{~mm}$ rainfall per year as the upper limit for the present distribution of dry plant formations in northeast Brazil. He noted, however, that the number of dry months per year is also an important factor and that the local relief may create climatic conditions favorable to the development of forest formations in otherwise prohibitively dry regions. The results of the analyses undertaken in this work are in agreement with these ideas and demonstrate that the break point in precipitation for the establishment of seasonal dry forests in northeast Brazil is $1000 \mathrm{~mm}$ rainfall per year and at least eight months receiving less than $100 \mathrm{~mm}$.

Our results suggest that the Borborema Plateau functions as a geographic barrier separating the humid and dry floras and support the view that the seasonal forests in northeastern Brazil comprise two separate floras, one associated with the Atlantic Coastal forest and the other with a different floristic domain, the xerophytic caatinga.

\section{Final Considerations}

The study carried out indicates that seasonal forests closer to the Atlantic coast are floristically distinct from those located further inland, even though they may share some taxa. In this respect, Oliveira-Filho et al. (2006) commented that, distribution patterns of tree species from seasonally dry tropical forest of eastern tropical and subtropical South America were influenced by a strong latitudinal gradient. Therefore, Atlantic moist and seasonal forests in a given region were floristically closer to each other than they were to similar forests types in different regions.

The seasonal forests of northeastern Brazil have long been interpreted as Pleistocene refuges of a more humid forest. The environmental laws of Brazil even recognize them as enclaves of the Atlantic Coastal Forest. It is important to emphasize that there are differences between the seasonal forests occurring to the east of the Borborema Plateau which have floristic relationships with the Atlantic coastal forest, and those found to the west, on the isolated weathered massifs and the low mountains within the semi-arid core, which have floristic links with the caatinga.

\section{References}

ALCOFORADO FILHO, FG., SAMPAIO, EVSB. and RODAL, MJN., 2003. Florística e fitossociologia de um remanescente 
de vegetação caducifólia espinhosa arbórea em Caruaru, Pernambuco. Acta Bot. Bras., vol. 17, no. 2, p. 289-305.

ANDRADE, GO., 1977. Alguns aspectos do quadro natural do Nordeste. SUDENE. Recife: Coordenação de planejamento regional - Divisão de Política Espacial.

ANDRADE, KVS. and RODAL, MJN., 2004. Fisionomia e estrutura de um remanescente de floresta estacional semidecidual de terras baixas no nordeste do Brasil. Revta. Brasil. Bot. vol. 27 , no. 3 , p. $463-474$

ANDRADE-LIMA. D., 1966. Vegetação. Atlas Nacional do Brasil. Rio de Janeiro: Conselho Nacional de Geografia IBGE.

-, 1981. The caatinga dominium. Revta. Brasil. Bot., vol. 4, no. 1 , p. $149-153$.

BARBOSA, MRV., 1996. Estudo florístico e fitossociológico da Mata do Buraquinho, remanescente de Mata Atlântica em João Pessoa, PB. Campinas: Universidade Estadual de Campinas. [Ph.D. Thesis]

BARBOSA, MRV., AGRA, MF., SAMPAIO, EVSB., CUNHA, JP. and ANDRADE, LA., 2004. Diversidade florística da Mata de Pau Ferro, Areia, Paraíba. In Pôrto, KC., Cabral, JP. and Tabarelli, M. (Orgs.). Brejos de altitude em Pernambuco e Paraíba: história natural, ecologia e conservação. Brasília: Ministério do Meio Ambiente. p. 111-122.

BEHLING, H., ARZ, HW., PÄTZOLD, J. and WEFER., G., 2000. Late Quaternary vegetational and climate dynamics in northeastern Brazil, inferences from marine core GeoB 3104-1. Quaternary Sci. Rev., vol. 19, no. 10, p. 981-994.

CORREIA, MS., 1996. Estrutura da vegetação da mata serrana de um brejo de altitude de Pesqueira, PE. Recife: Universidade Federal de Pernambuco. [M.Sc. Dissertation]

DRUMOND, MA., LIMA, PCF., SOUZA, SM. and LIMA, JLS., 1979. Sociabilidade de algumas espécies que ocorrem na Caatinga. In: Sociedade Botânica do Brasil (Ed.). Resumos do Congresso Nacional de Botânica do Brasil. Campo Grande: Sociedade Botânica do Brasil. p. 32-33.

FERRAZ, EMN., RODAL, MJN., SAMPAIO, EVSB. and PEREIRA, MRC., 1998. Composição florística em trechos de vegetação de caatinga e brejo de altitude na região do Vale do Pajeú, Pernambuco. Revta. Brasil. Bot., vol. 21, no. 1, p. 7-15.

FERRAZ, EMN., RODAL, MJN. and SAMPAIO, EVSB., 2003. Physiognomy and structure of vegetation along an altitudinal gradient in the semi-arid region of northeastern Brazil. Phytocoenologia, vol. 33, no. 1, p. 71-92.

GADELHA-NETO, PC. and BARBOSA, MRV., 2000. Levantamento florístico e fitossociológico de um remanescente de caatinga no município de Sousa, Paraíba. In Souza, MFV. (Ed.). Iniciados. João Pessoa: Universidade Federal da Paraíba. p. $64-87$

GAUCH, HG, 1982. Multivariate analysis in community Ecology. New York: Cambridge University Press.

GENTRY, AH., 1995. Diversity and floristic composition of neotropical dry forests. In Bullock, SH., Mooney, HA. and Medina, E. (Eds.). Seasonal Dry Tropical Forests. Cambridge: Cambridge University Press. p. 146-194.

GIULIETTI, AM., HARLEY, RM., PAGANUCCI, LQ., BARBOSA, MRV., DU BOCAGE NETA, AL. and
FIGUEIREDO, MA., 2002. Espécies endêmicas da Caatinga. In Sampaio, EVSB., Giulietti, AM., Virgínio, J. and Gamara Rojas, CFL. (Eds.). Vegetação and Flora da Caatinga. Recife: Associação Plantas do Nordeste. p. 103-118.

GUEDES, MLS., 1998. A vegetação fanerogâmica da Reserva Ecológica de Dois Irmãos. In Machado, ICS., Lopes, AV. and Porto, KC. (Eds.). Reserva Ecológica de Dois Irmãos: estudos em um remanescente de Mata Atlântica em área urbana, Recife,Pernambuco. Recife: Editora Universitária. p. 157-172.

HILL, MO., 1979. A FORTRAN Program for Arranging Multivariate Data in an Ordered Two-way Table by Classification of Individuals and Attributes. New York: Cornell University.

JATOBÁ, L., 1983. Alguns aspectos morfoclimáticos dos ambientes secos. Revta. Geog., vol. 3, no. 1, p. 67-89.

KENT, M. and COKER, P., 1992. Vegetation description and analysis: a practical approach. London: John Wiley \& Sons.

LOURENÇO, CEL. and BARBOSA, MRV., 2003. Flora da Fazenda Ipuarana, Lagoa Seca, Paraíba: Guia de campo. Revta. Nord. Biol., vol. 17, no. 1-2, p. 25-60,

MOREIRA, AAN., 1977. Relevo. In IBGE. Geografia do Brasil: Região Nordeste. Rio de Janeiro: IBGE. p. 1-45

MURPHY, G., and LUGO, AE., 1995. Dry forests of Central America and the Caribbean. In Bullock, SH., Mooney, HA. and Medina, E. (Eds.). Seasonal Dry Tropical Forests. Cambridge: Cambridge University Press. p. 9-34

NASCIMENTO, ART., FELFILI, JM. and MEIRELLES, EM., 2004. Florística e estrutura da comunidade arbórea de um remanescente de Floresta Estacional Decidual de encosta, Monte Alegre, GO, Brazil. Acta Bot. Bras., vol. 18, no.3, p. 659-660.

OLIVEIRA-FILHO, AT., JARENKOW, JA. and RODAL, MJN., 2006. Floristic relationships of seasonally dry forests of eastern South America based on tree species distribution patterns. In Pennington, RT., Lewis, GP. and Ratter, JA. (Orgs.). Neotropical savannas and dry forests: Plant diversity, biogeography and conservation. Boca Raton: Taylor \& Francis. p. 11-51.

PENNINGTON, RT., PRADO, DE. and PENDRY, CA., 2000. Neotropical seasonally dry forests and Quaternary vegetation changes. J. Biog., vol. 27, no. 2, p. 261-273.

PENNINGTON, RT., LAVIN, M., PRADO, DE., PENDRY, CA., PELL, SK. and BUTTERWORTH, CH., 2004. Historical climate change and speciation: Neotropical seasonally dry forest plants show patterns of both Tertiary and Quaternary diversification. Phil. Trans. R. Soc. London, vol. 359, no. 1443, p. 315-338 B.

PEREIRA, IM., ANDRADE, LA., BARBOSA, MRV. and SAMPAIO, EVSB., 2002. Composição florística e análise fitossociológica do componente arbustivo-arbóreo de um remanescente florestal no agreste paraibano. Acta Bot. Bras., vol. 16, no. 3, p. 357-369.

RODAL, MJN., 1992. Fitossociologia da vegetação arbustivoarbórea em quatro áreas de Caatinga em Pernambuco. Campinas: Universidade Estadual de Campinas. [Ph.D. Thesis].

RODAL, MJN. and NASCIMENTO, L. M., 2002. Levantamento florístico da floresta serrana da Reserva Biológica de Serra Negra, microrregião de Itaparica, Pernambuco, Brasil. Acta Bot. Bras., vol. 16, no. 4, p. 481-500. 
RODAL, MJN. and NASCIMENTO, L. M., 2006. The arboreal component of a dry forest in Northeastern Brazil. Braz. J. Biol., vol. 66 , no. 2 a, p. 479-492.

RODAL, MJN., LUCENA, MFA., ANDRADE, KVSA. and MELO, AL., 2005. Mata do Toró: uma floresta estacional semi-decidual de terras baixas no nordeste do Brasil. Hoehnea, vol. 32, no. 2, p. 1-12.

SAMPAIO, EVSB., ANDRADE-LIMA, D. and GOMES, MAF., 1981. O gradiente vegetacional das Caatingas e áreas anexas. Revta. Brasil. Bot., vol. 4, no. 1, p. 27-30.

SARMIENTO, G., 1975. The dry plant formations of South America and their floristic connections. J. Biog., vol. 2, no. 4, p. 233-251.

SILVA, FBR., RICHÉ, GR., TONNEAU, JP., SOUZA NETO, NC., BRITO, LTL., CORREIA, RC., CAVALCANTI, AC., SILVA, FHBB., SILVA, AB., ARAÚJO FILHO, JC. and LEITE, AP., 1993. Zoneamento agroecológico do nordeste: diagnóstico do quadro natural e agrossocioeconômico. Petrolina: EMBRAPA - CPATSA/ CNPS. 2 v.

SIQUEIRA, DR., RODAL, MJN., LINS e SILVA, ACB. and MELO, AL., 2001. Physiognomy, structure and floristics in an area of Atlantic Forest in Northeast Brazil. In Gottsberger, G. and Lied, S. (Eds.). Proceedings of Life Forms and Strategies in Tropical forests. Berlin, Stuttgart: Gebr.Borntraeger Verlagsbuchhandlung. p. 11-27.
SOUZA, GV., 1983. Estrutura da vegetação da Caatinga hipoxerófila do Estado de Sergipe. Recife: Universidade Federal Rural de Pernambuco. [M.Sc. Dissertation].

SUDENE, 1990a. Dados pluviométricos mensais do Nordeste. Estado da Paraíba. Recife: Superintendência do Desenvolvimento do Nordeste. (Pluviometria, 5).

-, 1990b. Dados pluviométricos mensais do Nordeste. Estado de Pernambuco. Recife: Superintendência do Desenvolvimento do Nordeste. (Pluviometria, 6).

-, 1990c. Dados pluviométricos mensais do Nordeste. Estado de Sergipe. Recife: Superintendência do Desenvolvimento do Nordeste. (Pluviometria, 8).

TAVARES, MC., RODAL, MJN., MELO, AL. and LUCENA, MFA., 2000. Fitossociologia do componente arbóreo de um trecho de Floresta Ombrófila Montana do Parque Ecológico João Vasconcelos Sobrinho, Caruaru, Pernambuco. Naturalia, vol. 25, no.1, p. 17-32.

TAVARES, S., PAIVA, FAV., TAVARES, EJS. and CARVALHO, GH., 1975. Inventário florestal da Paraíba e do Rio Grande do Norte l. Estudo preliminar das matas remanescentes do vale do Piranhas. Recife: SUDENE. (Recursos Naturais, 3).

VELOSO, HP., RANGEL FILHO, ALR. and LIMA, JCA., 1991. Classificação da vegetação brasileira, adaptada a um sistema universal. Rio de Janeiro: IBGE. 